$\xi=$ 离

\title{
An analysis about knowledge, attitudes, beliefs and practices of HIV and AIDS among the Himba people of the Kunene region, Namibia
}

\author{
Filippine Nekulu Nakakuwa ${ }^{1 *}$, Kabwebwe Honoré Mitonga ${ }^{2}$, Josephine de Villiers ${ }^{1}$, Scholastika Iipinge ${ }^{3}$ \\ ${ }^{1}$ University of Namibia, School of Nursing \\ ${ }^{2}$ University of Namibia, School of Public Health \\ ${ }^{3}$ Welwitchia University \\ *Corresponding author E-mail: fnakakuwa@unam.na
}

\begin{abstract}
Objectives: To evaluate the knowledge, attitudes, beliefs, practices and risk perceptions with regard to HIV/AIDS among the Himba people from the Kunene region; and to identify its determinant factors.

Design: The research study was quantitative. That is, cross sectional, descriptive and analytical. A total of 290 respondents were posed a number of multiple-choice questions about specific areas: HIV modes of transmission, knowledge on prevention measures, wrong conceptions of HIV/AIDS, beliefs, attitudes and practices.

Results: In this study, the mean overall score of knowledge of HIV/AIDS and its transmission modes was found to be 15.8 out of 30 with a $95 \%$ confidence interval of [15.1]; [16.5]. It was found that the Himba people's knowledge on HIV/AIDS does not differ according to the gender of the respondent. In fact, the mean score of knowledge of HIV/AIDS and its modes of transmission among females was 15.9 with a confidence interval of [15.1]; [16.8], whilst the mean score of knowledge of HIV/AIDS and its modes of transmission among males was 15.7 with a confidence interval of [14.5]; [16.8]. Using a bivariate analysis, factors such as condom use as a safer sex practice, level of education, type of marriage, and the gender of the respondents showed a statistically significant association with HIV knowledge at a 0.05 level of significance.

Conclusion: There is a need to increase knowledge that can be translated into change in behaviour and practices among the Himba, the efforts of all stakeholders are required. Such efforts include promoting education through mobile schools, intensifying sex education within the community through outreach programmes and putting in place policies integrated with indigenous cultural practices that will lead to positive attitudes and beliefs.
\end{abstract}

Keywords: HIV; AIDS; Himba; Nomadic Ethnicity; Kunene Region; Namibia.

\section{Introduction}

Namibia is one of the countries affected by HIV, with an HIV prevalence rate of $18.2 \%$ according to the 2012 National Sentinel Survey, compared with $4.2 \%$ in 1992 (Ministry of Health and Social Services (MOHSS),2012). HIV and AIDS remain the gravest development challenge for Namibia. With $23 \%$ of deaths being AIDS-related, the impact on the epidemic is deep, multi-sectoral, and intergenerational.

Kunene is one of the 14 regions in Namibia. It has a surface area of 144,255 square kilometres and is home to the Himba ethnic group. According to the Namibia 2011 Population and Housing Census main report, Kunene has a population of 86,856 (Republic of Namibia and Namibian Statistic Agency, 2013). However, Kunene remains underdeveloped and this may be due to its rugged, dry, remote and mountainous terrain, which significantly hinders infrastructural development. Opuwo is the capital of the Kunene region, and most of the Himba people live here. Between 1994 and 2006, Opuwo was reported to have a low HIV prevalence rate, despite an average increase of $1 \%$ annually. It was rated fourth in HIV prevalence in Namibia in 2008 and third in 2012 (MOHSS, 2012).
The Himba people are an independent pastoral society that lives in the rocky terrain of North West Namibia in the Kunene region. The Himba have lived in relative isolation and even the successive colonial administrations rarely interacted with them (IWGIA, 2004). HIV prevalence among the Himba is considered low at $7 \%$, compared to the national average of $20 \%$. Historically, Himbas are a healthy community with a unique life style and diet, and with malaria, tuberculosis and sexually transmitted diseases as their most common illnesses. IWGIA attributes low HIV infection among the Himba to their geographical isolation and strong cultural sexual practices; however, practices such as polygamy and the lack of sexual independence among women may likely reverse this trend (IWGIA, 2004).

HIV/AIDS activities related to prevention, treatment, care and support have been supported throughout all the regions of Namibia, but doubts remain as to whether the Himba people actually have knowledge and understanding on HIV/AIDS-related issues. The Himba as a community has not embraced education and prefer traditional medicine to modern medicine. Women have minimal choices with regard to husbands, since they are married off at a tender age; while wife inheritance after loss of a husband is commonly practiced, with polygamy prevalence estimated at $17 \%$ in Kunene (MOHSS \& Macro, 2008). Data from the Namibia 
Demographic and Health Survey (MOHSS \& Macro, 2008) indicate that only $38.8 \%$ of women and $62.4 \%$ of men in Kunene region have comprehensive knowledge of HIV/AIDS. However, the survey did not indicate which tribe has less understanding about HIV/AIDS since the region has six different ethnic groups: the Himba, Herero, Zemba, Damara, Nama and Owambo (MOHSS \& Macro, 2008).

\section{Method}

This research applied a quantitative study design. In fact, a quantitative, cross-sectional descriptive, exploratory design was used to analyses the knowledge, attitudes, beliefs and practices relating to HIV/AIDS among the Himba people from the Kunene region in 2014. The study focused on the knowledge, attitudes, beliefs and practices of the Himba people aged 15 years and above, both male and female. In this study, random systematic sampling was utilised. The six research assistants (Health Extension Workers) were selected and asked to provide a list of people living in their villages (from their census register). They were then each asked to interview 39 Himba people. The sample size was calculated using a sample size formula: $\mathrm{n}=\mathrm{N} / 1+\mathrm{Ne}^{2}$ where $\mathrm{N}$ is the target population, $\mathrm{n}$ is the sample size, and $(0.05)$ or $5 \%$ were the margin of error considered by the study (Israel, 2009) for Epupa constituency. Based on the calculation and a published table (Annexure F), a sample size of $\pm 7 \%$ precision, giving a confidence level of $95 \%$ and $p=0.05$, was selected (Israel, 2009), which is equivalent to 197 Himba people.

We collected data by administering a structured questionnaire which contained open and closed-ended questions. However, the questions essentially assessed basic information regarding people's knowledge about HIV and AIDS, their attitudes regarding HIV and AIDS, the specific practices that they follow and their particular beliefs regarding HIV and AIDS.

Computer software, namely SPSS, was used to analyse the data Descriptive statistics were used to describe and summarise the data. In addition, descriptive statistical procedures were applied to describe and calculate the central tendency parameters of the scores of the knowledge, attitudes and practices regarding HIV/AIDS, as well as the socio-demographic variables relating to the Himba people. Statistical tests of a non-parametric nature were employed and a conventional level of significance of 0.05 was used to detect differences. A chi-squared test was used to test for relationships between the dependent (level of knowledge, practices, beliefs and attitudes) and independent (demographic information) variables of the study population.

\section{Results}

\subsection{Socio- demographic}

The minimum age was 15 years, and the maximum age was 70 The mean overall age was 29.3 years with a $95 \%$ confidence interval of [28.0]; [30.7] years. In terms of gender, the mean age for females was 27.8 years with a $95 \%$ confidence interval of [26.2 29.4] years, whilst the mean age for male was 30.9 with a $95 \%$ confidence interval of [29.6]; [32.2] years. The study also established marital status in that the majorities $(53 \%)$ of the Himba respondents were single compared to $43 \%$ who were married. Less than $4 \%$ of the respondents were categorized under other forms, such as divorced, widowed or separated. Out of a total of 290 respondents, $63 \%$ stated that they had never been to school, while $25 \%$ indicated primary level education and $12 \%$ had attained secondary education.
Table1: Percentage Distribution of the Himba Respondents by SocioDemographic Characteristics

\begin{tabular}{lll}
\hline Age of respondents & Frequency & Percentage \\
\hline 24 years or less & 121 & 41.7 \\
25-30 years & 76 & 26.2 \\
31-40 years & 55 & 19.0 \\
41-50 year & 20 & 6.9 \\
50 or more years & 18 & 6.2 \\
Total & $\mathbf{2 9 0}$ & $\mathbf{1 0 0}$ \\
Sex of respondents & & \\
Female & 147 & 50.7 \\
Male & 143 & 49.3 \\
Total & $\mathbf{2 9 0}$ & $\mathbf{1 0 0}$ \\
Level of education attainment & & \\
None & 184 & 63.4 \\
Primary & 71 & 24.5 \\
Secondary & 33 & 11.4 \\
Tertiary & 2 & 0.7 \\
Total & $\mathbf{2 9 0}$ & $\mathbf{1 0 0}$ \\
Marital status & & \\
Married & 126 & 43.4 \\
Single & 153 & 52.8 \\
Others & 11 & 3.8 \\
Total & $\mathbf{1 0 0}$ \\
Type of marriage/relationship & & \\
Monogamy & 221 & 76.2 \\
Polygamy & 69 & 23.8 \\
Total & $\mathbf{2 9 0}$ & $\mathbf{1 0 0}$ \\
\hline & & \\
\hline
\end{tabular}

\subsection{HIV and aids knowledge}

As shown in table 1, the findings revealed that information related to HIV/AIDS comes from various sources. Most prominent of these sources among the Himba community, as indicated in table 2, are the following: $64 \%$ derive their HIV/AIDS information from health workers, followed by $21 \%$ of the respondents who reported friends as a major source of HIV/AIDS information. Only $3 \%$ mentioned family members as a source of information, while $12 \%$ reported other sources (newspapers, churches, radios and traditional leaders).

Table 2: Common Sources of Information, Sex Partners and Reasons for Condom Use

\begin{tabular}{lll}
\hline Common sources of HIV\&AIDS information & Frequency & Percentage \\
\hline Health workers & 187 & 64.5 \\
Friends & 61 & 21.0 \\
Family members & 8 & 3.1 \\
Others (newspapers, churches radio etc.) & 34 & 11.7 \\
Total & 290 & 100 \\
Sexual partners & & \\
1-2 partners & 171 & 59.0 \\
3-5 partners & 76 & 26.2 \\
6 or more sex partners & 43 & 14.8 \\
Total & 290 & 100 \\
Reasons for using condoms & & \\
Avoid pregnancy & 54 & 18.6 \\
Avoid STDs/HIV & 30 & 10.3 \\
Avoid both STD/HIV and pregnancy & 40 & 13.8 \\
No condom use & 166 & 57.2 \\
Total & 290 & 100 \\
\hline
\end{tabular}

The study investigated safer sex practices most especially condom use. It was accordingly revealed, as indicated in Table 2 , the majority $(57 \%)$ indicated not having used condoms, $24 \%$ used condoms to avoid HIV/STIs and pregnancy, while $19 \%$ used condoms as a control measure against pregnancy.

In this study, the mean overall score of knowledge of HIV/AIDS and its transmission modes was 15.8 out of 30 with a $95 \%$ confidence interval of [15.1]; [16.5]. The Himba people's knowledge on HIV/AIDS does not differ based on the gender of the respondents. In fact, the mean score of knowledge of HIV/AIDS and its modes of transmission among females was 15.9 with a confidence interval of [15.1]; [16.8], whilst the mean score of knowledge of HIV/AIDS and its modes of transmission among males was 15.7 with a confidence interval of [14.5]; [16.8]. The above results show that knowledge of HIV/AIDS and its transmission modes 
among the Himba community cannot be considered as acceptable (15.8 score out of 30). As illustrated in Table 3, the majority $(76 \%)$ of respondents were aware of diseases that are caused through sexual intercourse, especially STIs, with $89 \%$ mentioning syphilis. However, gonorrhoea was the least mentioned with only $39 \%$, meaning that the majority $(61 \%)$ of respondents did not know about gonorrhoea.

It is further illustrated in Table 3.3 that the majority (62\%) of respondents are aware of HIV/AIDS, with $88 \%$ being aware of how to avoid contracting HIV, $81 \%$ mentioning condom use as one way to avoid HIV, but only $14 \%$ mentioning abstaining from having multiple partners as a way to avoid HIV.

Table 3: HIV\&AIDS Knowledge Continued

\begin{tabular}{|c|c|c|c|}
\hline $\begin{array}{l}\text { Probing responses from } 290 \text { total re- } \\
\text { spondents }\end{array}$ & $\begin{array}{l}\text { Yes } \\
(\%)\end{array}$ & $\begin{array}{l}\text { No } \\
(\%)\end{array}$ & $\begin{array}{l}\text { Don't } \\
\text { know }(\%)\end{array}$ \\
\hline $\begin{array}{l}\text { Ever heard of a disease transmitted } \\
\text { through sexual intercourse (STDs) }\end{array}$ & 75.9 & 23.1 & 1.0 \\
\hline Ever heard of Gonorrhea & 39.3 & 60.7 & 0 \\
\hline Ever heard of syphilis & 89.3 & 10.7 & 0 \\
\hline Ever heard of HIV \& AIDS & 62.4 & 37.6 & 0 \\
\hline $\begin{array}{l}\text { Is there anything you can do to avoid } \\
\text { HIV? }\end{array}$ & 87.7 & 6.2 & 5.9 \\
\hline Use of condom & 80.7 & 19.3 & 0 \\
\hline Avoid multiple partners & 13.8 & 86.2 & 0 \\
\hline Sex abstinence & 8.3 & 91.7 & 0 \\
\hline Use of disposable syringes & 1.7 & 98.3 & 0 \\
\hline \multicolumn{4}{|l|}{ Wrong perception about HIV\&AIDs } \\
\hline $\begin{array}{l}\text { Can a person get HIV from using public } \\
\text { toilets? }\end{array}$ & 20.0 & 57.2 & 22.8 \\
\hline $\begin{array}{l}\text { Can a person get HIV from the mosquito } \\
\text { bite }\end{array}$ & 41.0 & 39.7 & 19.3 \\
\hline $\begin{array}{l}\text { Can a person get the HIV by touching } \\
\text { someone who has AIDS }\end{array}$ & 14.5 & 71.0 & 14.5 \\
\hline $\begin{array}{l}\text { Can a person get HIV by eating from the } \\
\text { same plate with someone with AIDS }\end{array}$ & 17.9 & 63.4 & 18.6 \\
\hline Knowledge on prevention measures & & & \\
\hline $\begin{array}{l}\text { Using a condom reduces chances of be- } \\
\text { coming infected with HIV }\end{array}$ & 76.9 & 14.1 & 9.0 \\
\hline $\begin{array}{l}\text { Having no sex keeps you from becoming } \\
\text { infected with HIV }\end{array}$ & 60.0 & 30.3 & 9.7 \\
\hline $\begin{array}{l}\text { Having faithful sexual partners keep you } \\
\text { not infected with HIV }\end{array}$ & 45.2 & 42.1 & 12.8 \\
\hline $\begin{array}{l}\text { Can you get infected having unprotected } \\
\text { sex with a person looking healthy }\end{array}$ & 53.4 & 32.4 & 14.1 \\
\hline
\end{tabular}

The study also established that $57 \%$ of the respondents mentioned that is it not right that one can get HIV by using a public toilet, $41 \%$ believed that mosquito bites can transmit HIV, while $40 \%$ rightly believe that mosquito bites cannot lead to one contracting HIV.Table 3.3 illustrates that the majority $(76 \%)$ of respondents were aware that using a condom reduces the chances of becoming infected with HIV. $60 \%$ of respondents were also aware that having no sex keeps one from becoming infected with HIV; while $45 \%$ believed that being faithful to your partner can prevent you from becoming infected by HIV, compared to $42 \%$ who say that is does not. 53\% were aware that having unprotected sex with a person who looks healthy can get one infected compared to $32 \%$ who were not aware.

\subsection{Practices and HIV/AIDS}

As illustrated in Table 4, 97\% of the study respondents were sexually active at the time of the study, with $73 \%$ having an extra sexual partner other than the spouse. The majority $(56 \%)$ reported having not used a condom during the last sexual encounter with a partner, and $43 \%$ of respondents did feel at risk of contracting HIV compared to $42 \%$ who did not feel at risk. The study also indicated that $70 \%$ of the respondents had never been tested for HIV, while $69 \%$ do negotiate safer sex with the spouse.In addition, $64 \%$ knew a place where they can get condoms in their local area, while $67 \%$ of the respondents were willing to use a condom duringeach sexual encounter.
Table 4: Practices, Attitudes and Beliefs about HIV\&AIDS

\begin{tabular}{|c|c|c|c|}
\hline Practices (290 total respondents ) & $\begin{array}{l}\text { Yes } \\
(\%)\end{array}$ & $\begin{array}{l}\text { No } \\
(\%)\end{array}$ & $\begin{array}{l}\text { Don't } \\
\text { know }(\%)\end{array}$ \\
\hline Are you sexually active? & 96.6 & 3.4 & 0.0 \\
\hline $\begin{array}{l}\text { If sexually active, do you have a sexual } \\
\text { partner other than your spouse? }\end{array}$ & 72.8 & 27.2 & 0.0 \\
\hline $\begin{array}{l}\text { Did you use a condom the last time you } \\
\text { had sex with a partner not your spouse? }\end{array}$ & 42.4 & 55.5 & 2.1 \\
\hline $\begin{array}{l}\text { Do you feel you are at risk of becoming } \\
\text { infected with HIV? }\end{array}$ & 43.1 & 42.4 & 14.5 \\
\hline Have you ever tested for HIV\&AIDS? & 30.3 & 69.7 & 0.0 \\
\hline $\begin{array}{l}\text { Do you negotiate for safer sex with your } \\
\text { spouse or sexual partner }\end{array}$ & 69.3 & 26.9 & 3.8 \\
\hline $\begin{array}{l}\text { Do you have a place you can get condoms } \\
\text { known to you in this area? }\end{array}$ & 63.8 & 29.7 & 6.2 \\
\hline $\begin{array}{l}\text { Are you willing to use condoms for each } \\
\text { sex intercourse? }\end{array}$ & 67.2 & 28.6 & 4.1 \\
\hline \multicolumn{4}{|l|}{ Attitudes } \\
\hline $\begin{array}{l}\text { Would you be willing to go for counseling } \\
\text { and testing? }\end{array}$ & 49.0 & 49.0 & 2.1 \\
\hline $\begin{array}{l}\text { Over the past year have you heard of any } \\
\text { message about HIV? }\end{array}$ & 71.0 & 26.6 & 2.4 \\
\hline $\begin{array}{l}\text { If you became infected with HIV would } \\
\text { you disclose to your family? }\end{array}$ & 72.4 & 23.8 & 3.8 \\
\hline $\begin{array}{l}\text { Would you be willing to care for } \\
\text { HIV\&AIDS patient? }\end{array}$ & 68.3 & 24.1 & 7.6 \\
\hline $\begin{array}{l}\text { Would you be willing to share utensils or } \\
\text { eat with a person HIV-positive? }\end{array}$ & 50.0 & 42.1 & 7.9 \\
\hline $\begin{array}{l}\text { Would you be willing to share toilet with } \\
\text { an HIV+ person? }\end{array}$ & 50.0 & 43.1 & 6.9 \\
\hline $\begin{array}{l}\text { Would you be willing to hold hands with } \\
\text { someone HIV+ }\end{array}$ & 61.4 & 32.1 & 6.6 \\
\hline $\begin{array}{l}\text { Would be willing to share a room with } \\
\text { someone HIV+ } \\
\text { Beliefs }\end{array}$ & 56.9 & 35.5 & 7.6 \\
\hline $\begin{array}{l}\text { Do you believe HIV\&AIDS is just a myth } \\
\text { (does not exist)? }\end{array}$ & 64.5 & 30.2 & 5.2 \\
\hline $\begin{array}{l}\text { Would you prefer going to the hospital or } \\
\text { traditional healer when sick? }\end{array}$ & 86.9 & 5.5 & 7.6 \\
\hline $\begin{array}{l}\text { Do you believe that traditional healers can } \\
\text { cure HIV\&AIDS? }\end{array}$ & 8.6 & 81.4 & 10.0 \\
\hline $\begin{array}{l}\text { Do you believe that witch craft causes } \\
\text { HIV/AIDS? }\end{array}$ & 30.7 & 54.5 & 14.8 \\
\hline $\begin{array}{l}\text { Do you believe it acceptable for married } \\
\text { couples to use condoms? }\end{array}$ & 34.1 & 55.5 & 10.3 \\
\hline Does a condom reduce sexual pleasure? & 51.7 & 27.2 & 21.0 \\
\hline $\begin{array}{l}\text { Do women have a right to demand the use } \\
\text { of condoms? }\end{array}$ & 33.4 & 59.0 & 7.6 \\
\hline
\end{tabular}

\subsection{Attitudes and HIV/AIDS}

As illustrated in Table 4, there was an equal proportion of $49 \%$ being willing and unwilling to go for HIV counselling and testing among the study population, while $71 \%$ had received or heard a message about HIV in the past 12 months, $72 \%$ believed they would disclose to a family if s/he became infected with HIV and $68 \%$ would be willing to care for an HIV/AIDS patient. It was further revealed in table 4 that half $(50 \%)$ would be willing to share utensils or eat with an HIV-positive person and share a toilet, as $61 \%$ and $57 \%$ were willing to hold hands and share a room respectively with an HIV-positive person.

\subsection{Beliefs and HIV/AIDS}

The majority (65\%) of the respondents" ${ }^{\text {ee }}$ believed HIV/AIDS is not a myth but that it does exist, with $89 \%$ preferring the hospital over a traditional healer when seeking health care. The majority $(81 \%)$ believed that traditional healers do not cure HIV/AIDS, while 55\% of the respondents believed that HIV is not caused by witchcraft. The majority (55\%) believed that it is acceptable for married couples to use condoms, while $59 \%$ believe that women have a right to use condoms. However, it was surprising to note that $52 \%$ of respondents believe that condoms reduce sexual pleasure. 


\subsection{Relationship between socio-demographic variables and HIV/AIDS knowledge among the Himba community}

In order to assess the influence of the socio-demographic characteristics of Himba respondents on knowledge, practices, attitudes and beliefs in HIV and AIDS, cross tabulations were done and the chi square statistic was used as a measure of association as illustrated below.

The study indicates no significant association between age of respondents and HIV knowledge among the study population, with $\mathrm{p}=0.157$. There is also a statistically significant association between the respondentsee gender and knowledge about HIV/AIDS, with $\mathrm{p}=0.000$. However, the married and single respondents a relatively large proportion showed that they were knowledgeable about HIV/AIDS, but no significant relationship between marital status and HIV/AIDS knowledge was found among the Himba population $(\mathrm{p}=0.991)$. There is also a statistical relationship between type of marriage and HIV/AIDS knowledge, with $\mathrm{p}=0.000$.

Table 5: Cross Tabulation between Socio-Demographic Factors and HIV\& AIDS Knowledge

\begin{tabular}{|c|c|c|c|}
\hline \multirow{2}{*}{$\frac{\text { Independent variables }}{\text { Age of respondents }}$} & \multicolumn{3}{|l|}{ Dependent variable } \\
\hline & Not Knowledgeable & Knowledgeable & Total \\
\hline Less or equal 24 years & 49 & 72 & 121 \\
\hline $25-30$ years & 21 & 55 & 76 \\
\hline $31-40$ years & 20 & 35 & 55 \\
\hline $41-50$ years & 9 & 11 & 20 \\
\hline $50+$ years & 10 & 8 & 18 \\
\hline Total & 109 & 181 & 290 \\
\hline \multicolumn{4}{|c|}{ Chi2 $(4)=6,628, p=0.157$} \\
\hline \multicolumn{4}{|l|}{ Sex of respondents } \\
\hline Female & 57 & 90 & 147 \\
\hline Male & 52 & 91 & 143 \\
\hline Total & 109 & 181 & 290 \\
\hline \multicolumn{4}{|c|}{ Chi2 $(1)=0.180, p=0.000$} \\
\hline \multicolumn{4}{|l|}{ Marital status } \\
\hline Married & 47 & 79 & 126 \\
\hline Single & 58 & 95 & 163 \\
\hline Others & 4 & 7 & 11 \\
\hline Total & 109 & 181 & 290 \\
\hline \multicolumn{4}{|c|}{ Chi2 $(2)=0.018, p=0.991$} \\
\hline \multicolumn{4}{|l|}{ Type of marriage } \\
\hline Monogamy & 85 & 136 & 221 \\
\hline Polygamy & 24 & 45 & 69 \\
\hline Total & 109 & 181 & 290 \\
\hline \multicolumn{4}{|c|}{ Chi $2(1)=0.303, p=0.000$} \\
\hline \multicolumn{4}{|c|}{ Level of education attained } \\
\hline No education & 76 & 108 & 184 \\
\hline Primary & 16 & 55 & 71 \\
\hline Secondary & 17 & 16 & 33 \\
\hline Tertiary & 0 & 2 & 2 \\
\hline Total & 109 & 181 & 290 \\
\hline \multicolumn{4}{|c|}{ Chi2 $(3)=11.874, p=0.008$} \\
\hline \multicolumn{4}{|l|}{ Sexual partners } \\
\hline $1-2$ & 57 & 114 & 171 \\
\hline $3-5$ & 31 & 45 & 76 \\
\hline 6 or more & 21 & 22 & 43 \\
\hline Total & 109 & 181 & 290 \\
\hline $\operatorname{Chi2}(2)=3.971, p=0.1$ & & & \\
\hline
\end{tabular}

A significant relationship was found between level of education and knowledge of HIV/AIDS among the study population, with $\mathrm{p}$ $=0.008$ and between condom use as a safer sex practice and HIV/AIDS knowledge, with $\mathrm{p}=0.019$. However, there was no significant relationship between sexual partners and HIV/AIDS knowledge among the Himba community $(\mathrm{p}=0.137)$.

Table 6, implies that it is not a lack of understanding about HIV/AIDS or a lack of access to condoms but rather other cultural practices and beliefs that define sexual practices in the study population. There was a statistically significant relationship between condom use as a safer sex practice and HIV/AIDS knowledge, with $\mathrm{p}=0.019$.
Table 6: Cross Tabulation of Socio-Demographic Variables and HIV/AIDS Knowledge

\begin{tabular}{llll}
\hline & \multicolumn{2}{l}{ Dependent variables } \\
Independent variables & \multicolumn{2}{l}{ HIV\&AIDS knowledge } & \\
\hline Why use condoms & $\begin{array}{l}\text { Not knowledge- } \\
\text { able }\end{array}$ & Knowledgeable & Total \\
Avoid pregnancy & 18 & 36 & 54 \\
Avoid STD/HIV & 4 & 26 & 30 \\
Avoid both STD/HIV and & 16 & 24 & 40 \\
pregnancy & 71 & 95 & 166 \\
No condom use & 109 & 181 & 290 \\
$\begin{array}{l}\text { Total } \\
\text { Chi2 }(3)=9.940, p=0.019\end{array}$ & & & \\
\hline
\end{tabular}

\section{Discussion}

\subsection{Demographic characteristics}

In our study the participants' age ranged between 15 and 70 years of age, of which $68 \%$ were under 30 years old. Therefore, it can be deducted that the study respondents tended to be the youth into the Himba community. There were an almost equal number of male and female Himba respondents, that is, $49 \%$ male versus $51 \%$ female. This was achieved because the study was rural based, and the Himba community tend to be concentrated around their grazing areas, which enabled the achievement of almost an equal proportion of gender.

$63 \%$ of the respondents had never attended school and only $12 \%$ had attained secondary education. By nature, the Himba community is a nomadic community; thus the low level of education does not come as a surprise. The study revealed that $24 \%$ of the respondents were in a polygamous relationship. This is higher than the NDHS 2006-07 survey indicated; that is, 17\% polygamy in the Kunene region (MOHSS \& Macro, 2008). This factor is important in that it gauges how vulnerable the respondents are because polygamous relationships are at times associated with risky behavior that promote HIV risk, especially partner unfaithfulness.

\subsection{HIV and AIDS knowledge and transmission mode}

The study revealed that the main sources of information about HIV/AIDS are health workers $(64 \%)$ and friends $(21 \%)$. This indicates that the Himbas do not have ready access to radio or television, or educational programmes, such as My Life is My Choice. The only HIV prevention method the Himba community was aware of was condom use (81\%).Of the respondents, $81 \%$ mentioned condom use as one way to avoid contracting HIV; moreover, $57 \%$ did not use a condom in the past six months. This shows that they lacked knowledge of condom use. This finding is in agreement with the results of Masoda (2010) and Meekers, Silva, and Klein (2003). A study in rural South Africa by Versteeg and Murray (2008) describes some of the reasons why condoms are not used consistently. These reasons include perceived and really physical side-effects, including reduced pleasure; distrust in the efficacy of condoms; gender-related reasons; and trust in relationships.

\subsection{Wrong perceptions about HIV and AIDS}

Of the respondents, $41 \%$ believe that mosquito bites can transmit HIV. These findings are consistent with a study conducted in Sana'a City in Yemen among students of health institutions (AiRabeei, Dallak, \& Al-Awadi, 2012). The findings of this study showed that $41.5 \%$ have misconceptions about how HIV and AIDS are transmitted.

\subsection{Practices and HIV/AIDS}

Ninety-seven per cent of the study respondents were sexually active at the time of the study, with $73 \%$ having an extra sexual partner other than the spouse. Fifty-six per cent had sexual inter- 
course without a condom and only $43 \%$ felt that they were at risk of contracting HIV. Moreover, $70 \%$ had never been tested for HIV. This result is consistent with those who were never tested in Kunene region (MOHSS \& Macro, 2008) $-69.5 \%$ of males and $53.4 \%$ of females.

\subsection{Attitudes and HIV/AIDS}

Persons with HIV/AIDS are likely to conceal their HIV status for fear of rejection and stigmatization. The survey sought to determine what proportion of respondents would be willing to disclose their status, having discovered that they had contracted HIV. Accordingly, $72 \%$ believed that they would disclose to a family member if s/he became infected with HIV. This is in agreement with a survey done, that is, the National Youth KABP Survey on HIV/AIDS (MOEYAS, 2001), which revealed that 74.7 of the respondents were also willing to disclosure their status. These findings show a high willingness for disclosure among the Himba people.

\section{Conclusion}

The results showed that knowledge of HIV/AIDS and its transmission modes among the Himba community cannot be considered as acceptable (a score of 15.8 out of 30). The study further confirmed the low consistent use of condoms among the Himba of the Kunene region of Namibia, despite the Himba population demonstrating adequate general knowledge of HIV and its transmission through unprotected sexual intercourse. Whilst there was some evidence that knowledge supports behavior (e.g. the association between knowledge that sex is the main way of transmitting HIV and consistency in condom use), on most parameters there seemed to be a gap between knowledge and practice.

The study concluded that the Himba community does not practically support the public health message of delayed sexual debut, which is an important strategy for reducing risky sexual behaviour in the youth. It is disappointing that the majority of respondents are sexually active and that, in an environment with a tendency for extramarital relations, there are no integrated efforts to regulate their sexuality. Generally, knowledge of HIV/AIDS and its transmission is widely publicised, and community awareness campaigns influence the knowledge, attitudes, beliefs, and sexual behaviour change and confidence of sexual practices. However, there were some misconceptions about HIV/AIDS treatment. Misconceptions concerning a „cure ${ }^{e c}$ for HIV/AIDS are one of the risk factors for contracting the virus. Awareness campaign may not remove this risk. However, as a paradigm shift is required, and the onus rests with the government and community initiatives to integrate or find ways of changing the misconceptions using various approaches.

\section{References}

[1] Al-Rabeei, N. A.,Dallak, A. M., \& Al-Awadi, F. G (2012).Knowledge, attitude and beliefs towards HIV/AIDS among students of health institutes in Sana'a city.Yemen: University of Sana"a and AL-Sabeen Hospital. Retrieved January 07, 2013 from http://applications.emro.who.int/emhj/v18/03/18_3_2012_0221_02 26.pdf

[2] Government of the Republic of Namibia (GRN). (2005). Population and housing census: National report basic analysis with highlights. Windhoek: Central Bureau of Statistics (National Planning Commission).

[3] International Work Group for Indigenous Affairs (IWGIA) (2004).Indigenous people's rights in Southern Africa. Copenhagen, Denmark: IWGIA.

[4] Israel, G.D. (2009). Determine sample size.RetrievedDecember 30, 2011 fromhttp://edis.ifas.ufl.edu/pdffiles/PD/PD00600.pdf

[5] Masoda, M. M. (2010).Knowledge, attitudes and practices of Goma University students about condom use in the purpose of reducing HIV infection.Limpopo University, South Africa.
[6] Meekers, D., Silva, M.\& Klein, M. (2003).Determinants of condom use among youth in Madagascar. Washington, DC: Population Services International, 55, 18.

[7] Ministry of Education, Youth Affairs and Sports (MOEYAS). (2001).National Youth KABP Survey on HIV and AIDS.Barbados: Division of Youth Affairs.

[8] Ministry of Health and Social Services (MoHSS). (2012).Report of the National HIV Sentinel Survey. Windhoek, Namibia.

[9] Ministry of Health and Social Services (MoHSS) and Macro International (Macro). (2008).

[10] Namibia Demographic and Health Survey 2006-07. Windhoek, Namibia and Calverton, Maryland, USA: MoHSS and Macro.

[11] Republic of Namibia and Namibia Statistic Agency. (2013).Namibia 2011 Population and Housing Census main report. Namibia, Windhoek.

[12] Versteeg,M., \& Murray, M. (2008). Condom use as part of the wider HIV prevention strategy: Experiences from communities in the North West Province, South Africa. J SocAspects HIV/AIDS, 5(2), 83-93. https://doi.org/10.1080/17290376.2008.9724905. 